\title{
Can China Be Populist? Grassroot Populist Narratives in the Chinese Cyberspace
}

\author{
Dr Ying Miao \\ Lecturer, Department of Politics and International Relations \\ Aston University, Birmingham, UK \\ B4 7ET \\ y.miao2@aston.ac.uk \\ +44(0)1212045028
}

\begin{abstract}
The current debate on populism is mostly Euro-American centric. Less attention is paid to how the rise of populist ideas echo and reverberate in other regions of the world. This paper examines how the core concepts to populism, namely 'the people', 'the elite' and 'the other', is constructed and contested in China. I show how the netizens contextualise the rise of populist right in America in relation to China, and how they construct a narrative of 'must learn lessons' for China out of the American experience, with identifiable populist elements. I argue that although non-establishment populist leaders or parties are unlikely to emerge under the one Party rule, the grassroot political narratives in China harbour significant latent populist tendencies, and the potential for populist rupture is real.
\end{abstract}

9,356 words

\begin{abstract}
Author Bio
Dr Ying Miao is a Lecturer in the Department of Politics, Aston University, Birmingham, UK. Her research interests include populism and identity politics, social stratification, and comparative development between China and the West. Her articles have appeared in the Journal of Contemporary China and Asian Studies Review, and her monograph, Being Middle Class in China, was published by Routledge in 2017.
\end{abstract}




\section{Introduction}

The rise of populism across the world has increasingly garnered the attention of scholars and commentators alike. Current research on populism is mostly concentrated in the EuroAmerican region, and the approach is often top-down as it focuses on populist movements, populist parties and leaders, especially concerning how populism presents as a mirror of representative democracies. Less attention is paid to the rise of populism in societies without an immediately identifiable populist leader or movement. Yet populism at its core is about the struggle between imagined political entities: the 'people' versus the 'elite', and the 'people' versus the 'other'. This kind of conflict or political chasm can be present in all societies, and not limited to democracy. Indeed, populism is particularly versatile and can cut across historical periods, geographic boundaries, and ideological cleavages (Gidron and Bonikowski 2013), and populist rhetoric can be diffused and adapted across countries (Sawer and Laycock 2009).

Therefore, even though the current discussion of populism is mostly in relation to democracies, the rise of populism in nondemocratic states should not be ignored. As Laclau wrote, "the emergence of populism is linked to a crisis of the dominant ideological discourse which is in turn part of a more general social crisis" (Laclau 1977). China in recent years could be said to have seen the advent of these two preconditions. It is now a popular consensus that the Chinese Communist Party (CCP) is undergoing a search for alternative sources of legitimacy as its claims on Marxism-Leninism weakens. Post-reform sociopolitical transitions and growing uncertainties associated with the global economic slowdown have seen a rise in social discontent and dissent, a crisis of trust and confidence that is felt particularly keenly in the internet sphere. The political style of Xi Jinping, which has sometimes been described as populist (Perry 2015), further adds to the relevance of exploring populism in the Chinese context.

This paper examines how the core concepts to right-wing populism, including 'the people', 'the elite', and 'the other' is constructed and contested in the Chinese cyberspace. It is organised in five main sections. First I will give an overview of populism and the different definitions and approaches taken by scholars in the field. I will briefly introduce the state of the Chinese Internet, and public opinion in the Chinese cyberspace, as well as the rationale and context for my enquiry. Focusing on the antagonistic relationship between 'the people' and 'the other' that is central to right-wing populism, I will then discuss how these key concepts and relationships are constructed and contested in China. I use Chinese netizen's response to Trumps' electoral victory as an example to show how the relationship between 
the people and the elite is depicted as one of direct answerability and paternalistic responsibility at the grassroot. I then will examine how the netizens contextualise the rise of populist right in America in relation to China, and how they construct a narrative of 'must learn lessons' for China out of the American experience, with identifiable populist elements. Finally, I will discuss whether it is useful to seek populism in China, as it seems contradictory at first glance. While a direct and systematic comparison of China and populism elsewhere would be difficult due to pre-existing differences in political institutions and context, we should not discount the latent populist tendencies embedded in these grassroot narratives, as they, like their counterparts elsewhere in the world, are expressions of sociopolitical discontent, which if left unaddressed, could be potentially explosive in the current global climate.

\section{Populism in Euro-American Contexts}

Populism as a political concept is difficult to pin down. It has many forms and is often argued to be lacking in core values (Taggart 2017; Canovan 2004), thus able to be applied to all forms of movements and governments. It has been considered as an ideology, a form of political logic, a type of discourse, a political strategy, and a political style; the general agreement in the comparative literature is that populism is "confrontational, chameleonic, culture-bound and context-dependent" (Art 2011).

When considering populism as an ideology, it is a 'thin-centred' one that "considers society to be ultimately separated into two homogeneous and antagonistic groups, 'the pure people' and 'the corrupt elite' and which argues that politics should be an expression of the volonté générale (general will) of the people" (Mudde and Kaltwasser 2017). The ideology is centred around the popular resentment of the people (inherently virtuous) against the elites (exploitative). The rise of mass society post-industrialisation especially means that the destruction of old social bonds and the emergence of a new commonality that can be called upon to be mobilised against the so-called elites (Germani 1978).

Populism has also been conceived as a political style, where populists overplay the perception of a threat or crisis with down to earth, "bad manners" and appealing to the people with their performances (Moffitt and Tormey 2014; la Torre 2017), and a political strategy, where a personalistic leader seeks or exercises government power based on direct, unmediated, uninstitutionalised support from large numbers of mostly unorganised followers" (Weyland 2017). Both the strategy and the style rely on an anti-status quo discourse that 
'simplifies the political space by symbolically dividing society between the people and the other' (Panizza 2005; Hawkins 2009), especially appealing to those in the low end of the socio-cultural spectrum (Ostiguy 2017), thus leading to the 'proletarianisation' of the rightwing populist support base, where the populist frontier is envisaged to be a cultural divide as a result of economic decline most sharply felt by the working class (Bornschier and Kriesi 2012).

When considering the underlying logic of populism and its effusive discourse, Laclau argues that populism only arises when there is a 'building up of an internal frontier dividing the social space into two camps', resulting in the construction of a 'popular subject' (Laclau 2005b). Thus, populism is a politics of difference, best operationalized as a political language that emphasises a fundamental divide between people and elites, upholding the primacy of the former and accusing the latter of attempting to capture social, political, and economic institutions for their narrow interests (Aslanidis 2017).

Regardless of conceptual approach, There are three key elements in populism: a central, antagonistic relationship between the people and the elite; an attempt to restore popular sovereignty, which implies that there is a transparent and readily accessible will of the people to all those willing to listen; and the idea of the people as homogenous unity, which often leads to antagonistic views against those who do not fit in (Abts and van Kessel 2015). However, most of the analyses on populism are top-down and after-the-fact, focused either on emerging populist 'politics in power' or the transformation of state discourse to fill a populist agenda (Robinson and Milne 2017). What, then, of regimes where populist forces are unlikely to gain political power, yet populist 'symptoms' and discourses are gaining in popularity? With this in mind, the paper will turn to examine how the three protagonists in populist discourse (the people, the elite, and the 'other') are narratively constructed and represented in the Chinese cyberspace.

\section{The Chinese Internet, Netizens and Online Public Opinion}

According to the official 40th Statistical Report on Internet Development in China, China's internet penetration rate is at $54.3 \%$ in June 2017, with 7.51 billion netizens, 5 billion of which come from urban areas (CNNIC 2017). Education and income are significant indicators of internet use: a large majority of internet users are concentrated in the most prosperous cities such as Shanghai, Beijing and Guangzhou. Generally it is seen that the internet has led to an increased awareness of the general public of the sociopolitical 
environment that they inhabit, and a greater need to express themselves politically (L. Peng 2008). Due to censorship and regulations, however, such participation often happens in nonconventional ways. Often unable to comment on domestic politics directly, topics of international politics are vibrant outlets of opinion on social media and offer valuable insight into how the participants approach politics as a whole. It is with this in mind that the netizen's response to Donald Trump's electoral victory in the 2016 American election was chosen as a topic for understanding how populist discourses are constructed at the grassroot in the Chinese cyberspace.

While the opinions of netizens cannot be substituted for the opinions of the whole society, it is nevertheless reflective of changing sociopolitical attitudes in China. Traditional media has always been the mouthpiece of the elites, and even more so due to China's propaganda system. Internet opinion, on the other hand, often post a stylistically and structurally opposite: by function, then, the internet is conducive to populism (Krämer 2014). In China, where opportunities for offline political participation is limited, online activity often can influence public and media opinion as a whole, and even affecting the direction and outcome of offline sociopolitical events (Bi 2015). Conventional media have also developed a symbiotic relationship with new media, as they often follow online cues to disseminate netizen's opinions to a wider audience. Thus, the internet can play a significant role in populism because it forces the government to recognise and respond to whatever issues the netizens are deeming unjust, in the absence of more robust intermediary legal institutions (Tang 2016).

\section{Sampling and Methods}

For this study, the website of Zhihu was chosen as the field site. Zhihu, meaning 'do you know?' in classical Chinese, is essentially a Quora-esque question and answer platform in China. According to official data, in 2017 Zhihu has 68 million registered users, 18.5 million daily active users, 75 billion pages views per month, with an average visit lasting 40 minutes (Zhihu 2017). According to two big data reports, university students, especially those from prestigious universities such as the 985/211 group, and white-collar professionals constitute the majority of the user base (J. Peng 2017; Yiyu 2017). Gender-wise the user base is more or less evenly split (51\% male to $48 \%$ female) and most of the user live in developed cities such as Beijing and Shanghai. The reason Zhihu, as opposed to Weibo, was chosen was because the nature of Zhihu's platform allowed elaborate answers compared to the 140 character limit of Weibo, and the upvotes system allows a relatively straight forward way to assess audience receptivity to the answers and ideas presented by each commenter. Furthermore, the topic of 
Trump's electoral victory was chosen because it was a protracted political event that gathered much attention in the Chinese cyberspace, and the answers to various populist elements in Trump's campaign were detailed, rich and varied, thus able to shed light on how netizens understood politics, both domestic and abroad, as a whole. Although the discussions surrounding Trump contains no anti-establishment agenda to challenge the domestic status quo, the way the netizens subsume and instrumentalise key populist logic and styles offers valuable insight into how politics is understood in contemporary China (Zhang 2019). Indeed, many answers directly drew parallel with China's past in their attempt to comprehend the outcome of the election, and forewarned similar fates befalling Chinese politics and society when they saw parallels with China's present.

Sampling was a multistage process. First, most popular questions under the topic Donald Trump was identified according to page views and number of followers to the question. Then, for each question, the most popular answers are recorded. The criteria for selection are that it must be an original answer by the commenter, have at least 1,000 upvotes or more, or ranked top 10 in the page. As Zhihu uses the Wilson interval for its algorithms, this allows the sampling to include both popular but controversial answers (an answer with a lot of upvotes but ranked lower means it has received a lot of downvotes as well), and answers that are both popular and less contested. A total of 65 answers from 7 most popular questions were collected. The sampled data are first coded line-by-line then analysed and organised into secondary themes using NVivo12.

\section{Grassroot Populist Narratives: Netizens' Response to Trump}

\section{The People}

All discussions of government, especially legitimate government, must involve the idea of 'the people', as all political associations are creations of its members and must in various ways respond to them (Kaltwasser et al. 2017). Whereas 'the people' as a source of political authority underlines modern democracy, the 'sovereign people' as a unified entity able to challenge and retrieve power from the state paves way for the rise of populism (Bourke and Skinner 2016). However, both the nature and the function of the people as a political entity is highly contested and often indeterminate. By populist identification, the people can refer to both the idea of the underdog (plebs) and as a holder of sovereignty (demos), or even the ethnos, and the populist discourse often emphasises the legitimate claims of the demos or ethnos being denied as they are made into plebs by the political establishment (Kazin 1998). In the populist view, politics is legitimised only if the people's will is followed, both as a 
constitutional ground and as a revolutionary force: whereas a democrat's claim to the invocation of the people is limited, populists draw their power from the unlimitable claims on the 'real voice' of the 'real people' (Espejo 2017). The simplification of politics, usually presented in antagonistic ways, is often the result.

The people-as-underdog discourse feature heavily in the Chinese netizen's Trump narrative. The people as a political group is seen as inherently virtuous, but in the current political climate, they are wronged, oppressed and voiceless. The reason for this people-as-underdog condition is attributed to the hypocrisy and ignorance of the governing elites. Contrary to their 'moral loftiness', the people are seen as down-to-earth, often struggling, in a political climate where political correctness has overshadowed their struggle for survival. Thus, 'the people' is immediately pitted against those who are deemed to have robbed them of their rights and livelihoods as legitimate productive citizens in the society: often the minority groups, who, according to the commenters, do not satisfy the moral criteria to be included in mainstream society.

The people don't care about political correctness, or social justice, they just want a better life. When they go out to find that better life, they find their jobs stolen by illegal immigrants. They can't afford utility, let alone university. They are angry - why are the mainstream media talking about things they don't care? Why are the immigrants stealing their jobs and why are the benefit queens robbing the country? (Gaius, 6600 upvotes)

The needs and the will of the people are generalised, and packaged to be simple, homogenous and easily graspable; indeed much of the outrage and indignation is directed at the seemingly deliberate ignorance of the elites towards the 'real problem': that honesty and hard work goes unrewarded and opportunistic minority groups are taking advantage of the people. Already we see that 'the people' is conceptualised to occupy a different discursive position to the 'other' and 'the elite', and the people's relationship with the former is seen as fundamentally antagonistic, while with the latter is with disappointment and antipathy.

First you need to be able to live. Then you need to be able to live well, and finally you can help others. The elites have mastered step two and three, and they are criticising those who haven't even managed step one, calling them a "basket of 
deplorables"1. But we are only at step one! We don't need to help the weak and the poor to feel good about ourselves! It's hard enough as it is staying alive...We only respect those who respect our efforts in keeping alive. We only respect those who like us, stay alive through hard work, and not by asking for handouts!" (WY, 5000 upvotes)

They continued to emphasise that people are realists, caring more about practical socioeconomic issues than abstract values and grandiose political goals. By suggesting that the elites overlooked the fundamental needs of the people, the commenters are essentially criticising the elites' lack of 'common sense' while overlooking the complexity of social problems, another recurrent theme in populist discourses.

"Equal rights is something that you [the elites] care about, not what the unemployed care about. If equal rights is what the people cared about, then Trump wouldn't have gotten into power. The people care about unemployment, and how their pleas for action go unanswered." (WY, 5000 upvotes)

Usually, populist rhetorics seek to draw upon the grievance of the ordinarily marginalised social sectors, with the goal to mobilise them into publicly visible and contentious political action (Roberts 2015a). However, it is worth noting that according to user demography, most of Zhihu's active users are white-collar and relatively well-off, a fact that is well acknowledged in the community, which considers itself 'middle class'. Nevertheless, their conception of 'the people' still see themselves and their peers as underdogs and powerless. The high sense of relative deprivation and material anxiety among the middle class could account for this (Miao 2017; Rocca 2016). While the political characteristics of the Chinese middle class has been shown to be social stabilisers due to their vested interests in the state (J. Chen 2013; Tomba 2004), the middle class in China have been squeezed in recent years due to rising costs of living, and limited social welfare as safety net (Miao 2016b). The perception of the middle class under threat is often the beginning of political simplification and leads to the polarisation of the rich vs the poor (Atkinson and Brandolini 2013). It is clear that the commenters are empathising with the poor and identifying them as their peers in the

1 Original English phrase used by the author. 
context of 'the people', as they did not hesitate to speak on the poor's behalf and advocate for their realpolitik:

“The poor wouldn't care about Trump's discrimination against women and Muslims. If following Washington would get you your own land, would you care if Washington had many slaves and many wives?" (WY, 5000 upvotes)

Thus the netizens understood the American election in populist terms: that the outcome of the election was an effective expression of the will of the people, despite the interventions of distrustful intermediary institutions such as the media, hence it was to be celebrated.

"The people have chosen what they want. The media always thinks as long as they control the dominant discourse they can deceive the people. No way!" (LYM, 1000 upvotes)

Trump's electoral victory is therefore seen to have uncovered the unifying qualities of the people: courage, honesty, and perseverance, as opposed to the misgiving qualities of 'the other'. The celebration of how 'real elites' have wrestled control back from the establishment echo the core tenants of populism elsewhere (Roberts 2015a).

\section{The Elites}

In populist discourses, the people often serve as an 'empty signifiers', as a marker for internal division, and calls forth a political subject that is in need of reclaiming its power, representation and sovereignty from the anti-popular 'other' (Laclau 2005a). This antipopulist other, usually the establishment and the elite, is therefore of significance, because in their role as the common enemy of the people, they also serve as the 'equivalential linkage' that can homogenise a variety of unsatisfied demands. Whether the 'elite' is understood in socioeconomic or cultural terms, the emphasis in populist rhetorics is always on the oppositional character of elites, or the powerful, to the people (Mudde 2004).

There is an interesting contrast between how the elites are conceptualised in populist discourses in Euro-America and in China. The elites in Chinese narratives are not seen as corrupt or anti-people by nature, as some populist discourses in Euro-America would suggest, instead, their narratives focus on the failure of the elites to carry out their paternalistic duty. As such, there is an underlying assumption that elites should be the champion of the will of the people, and do not necessarily have to occupy an opposite political space by their definition. The problem only arises when they misuse their position of power: 
"Elites like control... because they are overconfident and have vested interests. They think they know better than the plebs, so should own the plebs. More power, bigger government and wider intervention means the elites can better the people's lives, but this also means more opportunities for them to cheat the people out of their livelihoods." (Hui, 1200 upvotes)

At first glance it is contradictory to seek anti-elitism in China, as the vanguard nature of the CCP encourages paternalism and elitism. However, the concept of the elite is still constructed in relation to the concept of the people, and the elite status is legitimised or delegitimised according to how they react to the people's demands. Indeed, commenters contested the definition of 'real elites':

"Real elites do not depend on your Ivy League education or your fancy doctorate, or how much money you make and how old your family is. Real elite is stepping up for your country, to use your position, wealth and reputation for good, to lead the people and not to be led by the people, to make the country a better place. The Clintons just hide behind the Clinton Foundation. How dare they call themselves elite?" (RB, 4000 upvotes)

According to the commenter's logic, elite behaviour was more important than elite status; the established elites are seen as only protecting their self-interests, whereas to qualify as a 'real elite', one had to be responsive to the people's needs. The argument is perhaps unsurprising considering China's paternalistic political culture. According to Mencius' idea of people-based governance, for instance, the legitimacy of the ruling strata can only be established if they are seen to be reflecting and acting upon the people's will (Lee 1995). Conversely, popular revolt can be legitimised if the ruler is seen to have failed to carry out their paternalistic duty.

Hence, the commenters have concluded the primary reason for Hilary's electoral failure was her failure to grasp the will and the needs of the people. Once again the commenters make the assumption often central to populist discourses: that the will of the people is altogether transparent, homogeneous and easily accessible to those who would only listen (Abts and Rummens 2007). This was also an imagined victory of the people, as very few commenters acknowledge the fact Hilary won the popular vote. Instead, they focus on the transgression of the elites, having forgone their paternalistic role and lost touch with the people at the grassroot: 
"The elites have spent too long on the clouds... they have lost the ability to 'touch earth'. What is touching earth? It's the threat of survival, it's the fear of falling back into poverty overnight. This is not something that these people have to worry about." (WY, 5000 upvotes)

Similar to populist discourses elsewhere, there is a strong moralistic element to the narrative, as the netizens condemn those elites who neglect, devalue, or exploit the 'common people,' while celebrating the political empowerment of the underdogs as the redemption of the people (Roberts 2015b).

"[The elites] may cry for equality, but in their hearts they have divided people into different castes based on intelligence, qualifications, occupations and political views. They are full of contempt and hatred for those whom they do not consider one of their own. Because they think they are the winners in life, they broadcast that contempt widely in front of everyone, and in doing so turned their friends into enemies." (Yang, 2000 upvotes)

The commenters further distinguished two types of elites: the naive, represented by the students and intellectuals, and the self-interested, represented by politicians and business elites.

"There are two types of White Leftist elites... one that shouts whatever slogan that gets them votes, without even having to believe in them, like Hilary. They are not naive, they are just fake. The other kind are the intellectuals and students, who... [are] indoctrinated. They lack real-world experience and are addicted to empty words like 'world peace and equality for all'." (BDX, 4000 upvotes)

The overwhelming backlash against Trump in mainstream media and intellectual circles not only further discredited the 'fake elites', but legitimised Trump as a 'real elite', a champion of the people. Despite Trump's vast fortune and business empire, his media maltreatment made him an 'incongruent elite', who, despite sharing elite status relative to that of the working class, were either of a "marginal" status relative to incumbent elites and disaffected from the status quo (Di Tella 1965). The resentment towards intellectuals and their perceived comfortable lifestyle and economic wellbeing led to the commenters to be even more disdainful of their ignorance of the plight of the people: 
“The White Leftists who just won't grow up can’t do anything else, so they either write for White Leftist media platforms, or they become college professors and continue to poison the next generation." (THG, 1000 upvotes)

A pervasive sense of anti-intellectualism, or an arrogance of ignorance, which is a characteristic feature of populism (Wodak 2015), can also be observed here. Indeed, those who engage in mental labour are frequently placed in polar opposites from the workers, who are seen to represent the people in their hard work and industriousness. This mental vs manual mentality can be traced back to Mao's time, where mental work and high culture is regarded as oppressive and suspicious, whereas the vernacular and the popular are seen as virtuous and liberating (Townsend 1977). The commenters saw the fact that Trump enjoyed popular support among the American blue-collar workers as proof of Trump's legitimate claim to have championed the people's will, as he equated the notion of the people with workers and other productive members of society, as opposed to students or intellectuals.

"The experience of May Fourth has taught us that student strikes are useless, industrial strikes are what matters... but the American workers are not going on strike, are they? They are celebrating." (LYC, 8000 upvotes)

The discursive construction of the political order in terms of a binary elite-popular divide is often seen as a shared political logic of populism (Kaltwasser et al. 2017). When mobilised by populist parties or movements often in democratic contexts, this elite is portrayed as having disproportionate and unjustified control over conditions affecting the rights, wellbeing, and progress of 'the people' (Jansen 2011), and this is congruent with Chinese netizen's narrative construction of why Hilary, seen as the embodiment of establishment elites in America, lost the 2016 election. However, in their narrative, there is also a heavy moral emphasis on elite behaviour as opposed to elite status, where elites are expected to channel the will of the people, which is consistent with China's paternalistic political culture (Cheung 2012). Whereas populist discourses in democracies argue true virtue and authority rest with 'the people' and thus elites' authority is illegitimate, populist narratives in China does not necessarily place elites in the binary political order, but emphasise on the legitimacy of the elites which stems from their ability to champion the people's will. Under such narratives, 'real elite' can only be populist, as their legitimacy is not procedural or institutional, but performative. 


\section{The Other}

Social and political identities are relational and often depend on the identification of 'insiders' (us) and 'outsiders' (them) (Howarth 2000). Such discursive difference and resulting antagonism play a significant part in populist narratives. Populist discourses construct and give meaning to 'the people' as political actors, which claims to be the legitimate totality of a society or community, despite drawing a clear internal frontier against some imagined 'other' (Laclau 2005b). Thus, one of the core features of populism is how such narratives simplify complex developments by looking for scapegoats. As plurality and diversity in society is seen as a threat to 'denationalise one's nation, and deconstruct one's own people' (Pelinka 2013), the theme of the 'other' thus reflect what Laclau called 'social dislocation' and the associated frustrations that arise from the elite's perceived inability to deal with such grievances (Laclau 2005b). This moral emphasis of 'us vs them' is particularly prevalent in populist discourses in the Chinese cyberspace, where nativism and 'the mainstream' is celebrated, and 'the foreign' and 'the minority' shunned. Whereas the elites were mocked and their perceived failures are given in-depth postmortem analysis, the narrative stance towards the sociopolitical other as more hostile and often delve into easy stereotypes. Rage, indignation and fear are common emotional themes in these narratives, as they assume there are simple answers to their perceived sociopolitical discontent, but the elites are unwilling or unable to listen.

Rage and anxiety are common emotional features of populist discourse, because such widespread emotional states can be the link that bind together the masses and drive them into collective action (Di Tella 1965). Fear is also a critical tool in legitimising populist demands, which often appeals to the necessity of security (Wodak 2015). Here too, the narrative first establishes a popular source of rage, then seeks to justify that rage by claiming that the elites have ignored the needs of the people and instead teamed up with the enemies.

\footnotetext{
"The elites have pushed impractical social welfare schemes and asked honest labourers to pay the bill... they have wasted so much social resources, and the people can no longer bear the burden. What's worse is that they have decided to buy into the favour of those who make no contribution to society, such as illegal immigrants, for their votes." (Yang, 2000 upvotes)
}

As with other populist discourses, the relationship between the people (the mainstream) and the other is seen as one of antithesis, without hope of reconciliation. This is at its core a moral divide (Mudde 2017), where the people are seen as pure and the other seen as lecherous. This often goes hand in hand with ethnonationalism, which has become an increasingly salient 
feature in contemporary populism, where the narrative of the 'other' increasingly means 'enemies from abroad'. Although China is not yet an immigration destination, some respondents have warned that China is seeing similar signs of the 'polluting elements' infiltrating an otherwise pure society. Racist comments against Black and Muslim populations are common:

"In Guangzhou, the Blacks have formed their own communities, many of them are here illegally. They try to intermarry with the Chinese to stay in China... many hundreds of Chinese-African mixed kids have enrolled in our schools... Many hundreds of thousands of Muslims have also congregated near Yiwu, they build huge mosques to satisfy their own needs, and broadcast calls to prayer five times a day...Sometimes they marry Chinese girls, and all of the Chinese girls have to wear hijabs after marrying them."(XXT, 5,000 upvotes)

Permeating these othering and pathologising narratives were a sense of anxiety as well as anger, where authors warned that immigrants would bring foreign culture and form segregatory communities, and through intermarrying, they would subject Chinese women and children to alien culture and lifestyles. The author further incited the rage of the netizens by arguing that these immigrants were illegitimately reaping the rewards of China's economic development, which was built on Chinese people's blood and tears:

"The Chinese people work hard to build our own country, and for decades we were only allowed to have one child. We did not do this so that we can leave room for the illegal immigrants! I don't want to see 'XX lives matter' rallies in China and I don't want to see the Chinese people being called racists, after having our jobs stolen and our wallets robbed by these illegal immigrants. I don't want America's today for China's tomorrow, and the problem of race can't be solved." (NNS, 30,000 upvotes)

Similar to racist discourses found elsewhere, the authors universalise and objectify foreign populations and their behaviours in order to depict racial tension as a universal, natural phenomenon, a fact of life that cannot be avoided or fixed (Durrheim and Dixon 2000). In such discourses, there is a tendency to reconstruct China's ethno-racial identity against the 'inferior' non-Western other with racial nationalism (Zhang 2019). The discursive reasoning behind their argument, however, cannot be simply reduced to beliefs of Han supremacy. The authors do not proclaim that the Han Chinese are inherently superior to any other race, instead they emphasise the forbearance of the Chinese people through decades of reform, 
where personal sacrifice is made in the interest of national development. Therefore, any foreign contenders seeking to benefit from China's newly found economic prowess are seen as opportunists and marauders.

The excluding, demonising and pathologising narratives were not limited to the issue of race, but other minority social groups as well, such as LGBT:
"Look at this girl [screenshot of a Trump protester], she says Trump discriminates against lesbians. Have you seen her ears and neck? [She's tattooed and wears earstuds]. She's one of those people who says, I drink, I smoke and I tattoo myself, but I'm a good, respectable girl. In her eyes, if she isn't privileged, and we don't celebrate her kind every day, then it's called discrimination." (NNS, 30,000 upvotes)

The author argued here that the girl's claim for queer representation was invalid because she did not conform with the image of a respectable 'good girl'. In asserting her queer identity and wanting to be recognised, she had been automatically labelled as the 'other', as she opposed the interests of the mainstream. Indeed, the 'people vs the other' argument central to populist narratives are expressed as 'mainstream vs minority' in Chinese cyberspace, where the mainstream is the homogenous Chinese people, and the only legitimate body of expressing and enacting political will. Netizens are wary of how minority representation might overwhelm and overtake the mainstream, thus bring oppression to the people as a legitimate holder of political power.
"China should uphold mainstream views and be tolerant of minority views, rather than uphold minority views and suppress mainstream views and the mainstream population.” (YWS, 2,500 upvotes)

There is nevertheless still a distinction in attitude towards minority groups such as LGBT, and major out-groups such as immigrants. The former is only partially and sometimes rejected, as they are still seen as a part of the people, albeit with diverse characteristics and in minority. When faced with major out-groups such as foreigners and immigrants, they are expected to be bound with the people as expressed in these narratives, as their minority characteristics are subsumed by their overarching national identity. The major out-groups, however, are seen as marauders, inherently antagonistic to the people and without redemption: immigrants and benefit seekers, in these narratives, are wholly rejected and 
portrayed as the antithesis to the country's continued development. Figure 1 thus sums up the core elements of the populist narrative as constructed by netizens.

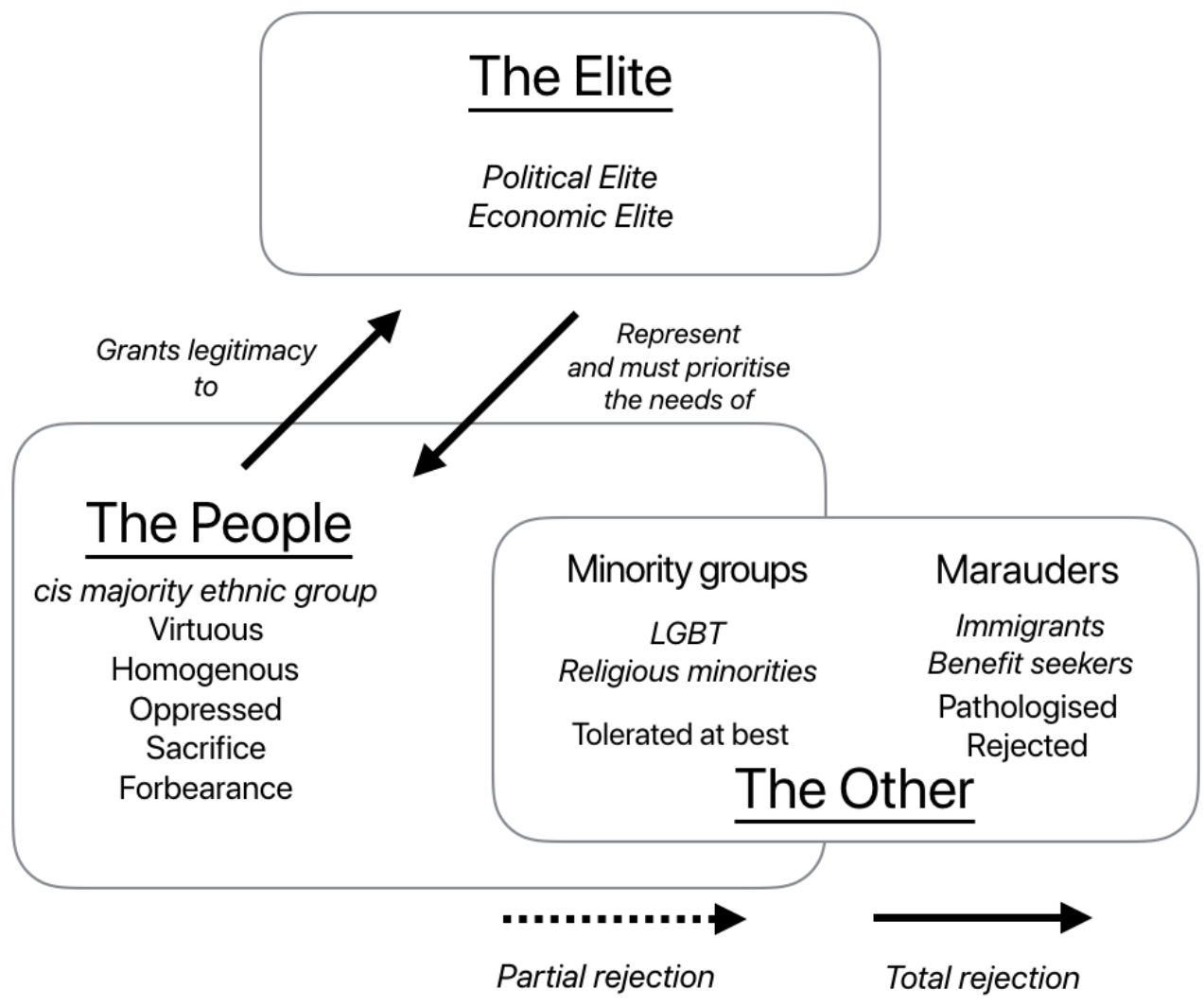

Figure 1: Summary of arguments found in grassroot populist narratives in Chinese cyberspace

\section{Lessons from the Past and Present: Constructing Populist Narratives in Chinese Cyberspace}

Despite not having a distinctive populist movement or populist leader in contemporary times, the political culture in China is fertile for populism. Although Confucian social hierarchy placed great emphasis on the prominence of the literati and elite, elements of populism have always existed in the form of 'peasant heroes' in Chinese folklore, as a part of counter-culture (Townsend 1977). Both the idea of Mandate of Heaven and Mencius' people-based governance legitimised the people's attempts to revolt when their needs went unfulfilled by the ruling elites (Ling and Shih 1998). The CCP in particular started as a revolutionary movement and for a long time relied on popular mobilisation as its principal political 
strategy. During the Mao era, the Party and the socialist goal was seen as the embodiment of the will of the general society, with Mao as a populist leader. Indeed, netizens made frequent analogies to Mao and even direct quotes from Mao when explaining the rise of Trump (emphasis indicates a direct Mao quote):
"What happened [that led to Hilary's defeat]?... is what exactly Generalissimo Chiang asked himself in 1949... [What happened was that] the people had no money, no voice, no channel to power. They were laughed at, mocked at, insulted at every day. They only had their votes. So they voted, and showed Hilary the meaning how a single spark can start a prairie fire." (Gaius, 6600 upvotes, emphasis added)

"Trump has overwhelming victories outside of cities... this is the meaning of countryside encircling cities. The whole country has turned red. [Trump supporters] finally expressed their view using their votes. Over Zhongshan swept a storm, headlong, Our mighty army, a million strong, has crossed the Great River." (Zhang, 30,000 upvotes, emphasis added)

In Mao's conception, the masses were of one mind, albeit they needed the Party's guidance from time to time. The idea of mass line essentially argues for the alignment of Party political goals with the interest of the masses, and in doing so bypasses institutional checks and balances that is usually present in the middle. Mass mobilisations and political movements during the Mao era were therefore essentially populist, in that 'virtue is seen to rest with the overwhelming majority of the people' (Ionescu and Gellner 1969). Under Mao, class struggle is essentially a form of enemy politics, which is a manifestation of populism (Weyland 2018); and the vernacular and the popular is celebrated whereas mental work and high culture is seen as oppressive, which is similar to how populism can be articulated through appealing to, and resonating with, the sociocultural 'low' (Ostiguy 2017).

Not only did the commenter saw the electoral support for Trump as mass mobilisation, but they also recognised the disruptive performance of Trump, and likened him to China's reformer, Deng Xiaoping.

\begin{abstract}
"Trump did a classic 'abandon ideology' move. He's gone for the 'black cat, white cat, whoever catches mice is a good cat' route, just like Deng. We the Chinese have been beneficiaries of these reforms for 30 years, so of course we agree with him.” (TPR, 2700 upvotes)
\end{abstract}


In this narrative, netizens largely agree with Trump being cast in a populist narrative as a fixer of malaise, and a righter of wrongs. They see China's developmental challenges in a framework of historical fatalism and believe the tried and tested methods of the neoliberal establishment elite have failed. Just as Deng's reform revitalised China when state socialism had failed, Trump would rejuvenate an ailing America:

"Deng said reform is crossing the river while groping stones. For the previous decade we relied on the USSR... now we are entering a new era. Fortunately, all the problems we will experience is happening right now in America... How do we deal with the rise of the middle class? How do we deal with immigration? How do we deal with all the sanctimonious urban dwellers? How do we deal with potential terrorism? Trump promises to deal with these problems his way, and I look forward to that." (Zhong, 3000 upvotes)

The overwhelming support for Trump on Zhihu became so self-evident that Zhihu users themselves started to ask why this was so. Many users agree that this, too, was due to China's historical experience, that the Chinese people have first-hand knowledge of 'the power of the masses'. There is a distinct sense of middle-class superiority in their narrative, where they empathised with populist leaders - the elite who understood the plight of the little man. Like populist discourses found elsewhere, they praise and stress the necessity of resonating with the 'low', thus further simplifying and polarising politics into opposing camps.

"The educated in China are respectful of... the power of the masses below. We are not just fearful of their power... we do not mock them or undermine them. Unlike the American elites, we are not shocked and surprised by their grievances, in fact we appreciate and emphasise with these grievances because we came from the lower classes too." (YJ, 6500 upvotes)

Furthermore, the authors used social Darwinistic ideas to justify why the American elites, whom they saw as complacent and naive, due to being raised in prosperity. This kind of moral reasoning not only feeds back into the narrative of elite failure, and also legitimises their backlash against the 'other'.

“...In China, even in first-tier cities, growing up without worrying about abject poverty is something that only happened after the 1990s. The American white lords have had this since the 1950s... if you grew up under prosperity, of course you are sweet and naive. We on the other hand, have just emerged from the 
jungle, and there are still people in the jungle fighting for their lives. Now America is suffering for its political correctness, and we may laugh. But what's going to happen when the new generation of kids who grew up in prosperity get older in China?" (LYC, 8000 upvotes)

Indeed, there is a strong backlash against the 'tyranny of political correctness', similar to right-wing critiques found in Euro-America, which argue that the overbearing climate of political correctness is a means of controlling language, institutionally excluding White populations, while refusing to talk about 'real' social problems (Rhodes 2010). The authors expressed an inherent distrust of such linguistic conformity, and drew similarities between political correctness and the ideological oppression of Mao's era, especially during the mobocratic rule of the Cultural Revolution. The Chinese can see 'political correctness movement for the tyranny that it is', they argued, because they had the experience of it in living memory.

"Political correctness is a terrible thing. It's a tool used to sweep away dissent, a symbol of stagnant minds and superstitious beliefs. Doesn't it sound familiar? Half a decade ago, we had a similar political movement. In America right now, as long as you paint the word 'equality' on the big character posters, you get a free pass, much like painting the words of Chairman Mao." (Zhang, 30,000 upvotes)

What is ironic is that many of the typologies the respondents used are reminiscent of the Mao-era language and ideologies. Even though they identify the political correctness movement as America's new Cultural Revolution, their language evokes anti-intellectualism and the celebration of mass mobilisation of the Cultural Revolution era. They have constructed a narrative where the White Leftists are the new Red Guards, and the people (more specifically Trump supporters) are being wrongly persecuted like the victims of the cultural revolution for having political views different to that of the mainstream. However, the language and symbolism in their answers evoke a nostalgic narrative of the cultural revolution: one where the people have triumphed over manipulative bourgeois intellectuals, and have smashed the old world order with their rage and defiance. This attitude can be summed up using a populist Mao-era slogan: "to rebel is to be justified". 


\section{Can China be Populist?}

At first glance, to seek populism in China is contradictory. Discussions of populism are usually juxtaposed against democracy, and there are no identifiable populist movements or parties in China's one-party authoritarian regime. Indeed most authors see populism as a pathology, a threat, or a shadow of democracy. What role might populism play, then, in existing authoritarian contexts? Populism certainly has an inherent tendency to turn authoritarian, which arises from its definitional characteristics: as long as leaders promise to resolve deep-seated structural problems, they have good chances to perpetuate themselves in office (Weyland 2018). Conversely, authoritarian leaders often resolve to populist goals and strategies in order to further their claims on legitimacy. National populism, for instance, has been conceptualised as a form of lower-class authoritarianism (Germani 1978).

Moreover, fundamental elements of populist narrative, and key features of populist logic, are not exclusive to any one type of political system. If we see populism as a dimension of political action, as Taguieff argues, then it can be synthesised with all forms of governments. The political use of populism is versatile: democracies can be hijacked and overturned by populist leaders, but authoritarian leaders can also legitimise themselves through populist means (Taguieff 1995). Indeed, populism is by no means irrelevant in China: the continuing ideology of mass line, weak institutionalisation and direct government response suggest that the country might be moving towards populist authoritarianism as its mode of rule (Tang 2016). Like Russia, which adopts populist rhetorics as a tool of regime stabilisation (Robinson and Milne 2017), in recent years we have seen top political figures in the CCP turning towards populism as a way to rekindle popular enthusiasm and support. The meteoric rise and fall of Bo Xilai proved that leaders can quickly amass and enjoy populist success, and while Bo's populist bid for leadership has failed, Xi Jinping has certainly incorporated populist styles and strategies to bolster his own support base (Fewsmith 2013). Henceforth, even though a non-establishment populist leader is unlikely to rise under the CCP's tight control, the CCP continues to rely at least partially on populist strategies in order to legitimise and secure political support.

More importantly, populism often arises out of sociopolitical discontent, which expresses itself along simplified and antagonistic forms of political order, with the idea of the 'people' at the core. The moral distinction of 'us' versus 'them' is at the core of this antagonism, which pits the people both vertically against the elite, and horizontally against the 'other' (Brubaker 2017). What is striking in the case of Chinese netizens discussed in this paper, is that they have subsumed and responded to the prevalent populist narratives surrounding 
Trump's electoral victory, and applied similarly polarising arguments to politics in general. Although there are no overt anti-establishment cries in these posts (not least because the Chinese cyberspace has little room for such challenges), it is clear that the netizens hold certain expectations over how the so-called elites and establishment should behave: any antagonism arising out of misrepresentation of the so-called people's interests are sympathised and legitimised. Thus, the netizen's narrative framing of politics takes an essentially polarising and populist form, which transcends national boundaries: the netizen's understanding of US politics here is a reflection of how they understand politics back home.

As we have seen, the moral divide of 'us versus them' is prevalent in Chinese netizen's narrative construction of the global political order. Part of this construction is encouraged by the official CCP discourse, where the appeal to the people is often an appeal to the ethnos rather than the demos (Carrico 2016). Underlying the populist nationalistic sentiments is a sense of moral commitment that grows out of membership in the community (Yong 2017), which feeds into the narrative that there are moral criteria for 'the people' or to qualify as 'the mainstream' in Chinese society. In enforcing social conformity and encouraging selfcategorisation of 'in-groups' and prejudice against 'out-groups' (Feldman 2003), China's authoritarian context is providing fertile ground for populist narratives and logic to flourish, if not the actual space for non-establishment populist leaders.

Furthermore, almost all populist parties in democracies have grown out of the antiestablishment mood, the socio-economic grievances and the feeling of insecurity of the populace. As China's economic growth slows down and the sense of relative deprivation rises among the Chinese public (X. Chen 2018), the only seemingly missing ingredient in this recipe is the anti-establishment mood. While it is well-known that the Chinese populace exhibits high levels of political trust towards its central government, the same cannot be said about popular trust towards the local government in China (Zhong 2018). This has a few implications in the context of emerging grassroot populist trends in China.

First, the lack of anti-establishment mood does not mean a lack of sociopolitical grievance, general or specific. In the netizen's narrative framework, they do not distinguish between political elites at the central level and the local level, but focus on the juxtaposition of the elites being different to the people. Although they have exhibited little anti-elite mood in the Chinese domestic context, the netizens have used such polarising and populist imaginings to legitimise their critique of elites in the US, whom they perceive as having failed in their paternalistic duty. The significance of such populist awareness should not be overlooked, even though the likelihood of it challenging the state in the current Chinese context is low. 
Another paradoxical implication of a mismatch in trust between central and local government is that the Chinese public often seek and expect paternalistic protection from the central government and even singular leaders, thus weakening intermediary institutions in the process. Indeed, there is evidence that bureaucratic fragmentation has led the central government to deliberately expose corruption at the local level to redirect public criticism away from the central organs (Manion 2004), and the protesters responding in kind by using central government rules and regulations to back up their grievances levelled against local governments and officials (O'brien and Li 2005).

Finally, due to the paternalistic expectation for the elites, there is also the threat of the establishment othering itself. As we have seen, netizens, who empathise with 'the people' and 'the masses', are only ready to accept elite leadership if the elites are seen as representing their interests. In ideology at least, the CCP has pledged this: in Party propaganda literature, the word 'people' is most often referred to as the base of support for the CCP. It is the CCP's fundamental mission to represent the 'interests of the people', which, like the imagined general will of the people in populist discourse, is seen as homogenous, transparent and easily accessible. However, this is a tight line to walk, because 'the people' is too elusive a concept, and 'the general will' too diverse and difficult to ascertain. When the people recognise and sanction the effort of the Party to purify its ranks, populist policies such as the anti-corruption campaign can work to increase the legitimacy of the CCP. On the other hand, as long as the $\mathrm{CCP}$ continues to emphasise the vanguard role of the Party and its cadres in juxtaposition with the people or the masses, it risks 'othering' itself, and risks being labelled as the exploitative elite as long as its performance fails to align with the expectations of the people. The tension between responsiveness and responsibility (Mudde and Rovira Kaltwasser 2018) that has led to the rise of populism in democratic regimes is not wholly absent in China's paternalistic authoritarianism. Therefore, although non-establishment populist leaders or parties are unlikely to emerge under the one Party rule, the grassroot political narratives in China harbour significant latent populist tendencies, and the potential for populist rupture should not be overlooked.

\section{Conclusion}

Populism at the core tries to deal with several essential questions: what went wrong, who is to blame, and how do we fix it? (Betz and Johnson 2004) In the Euro-American case, the answers are: the government (who is supposed to represent the people) has been hijacked by the elites, who are to blame for the social injustices, and the people, seen as a virtuous and 
homogenous entity, must reclaim their power through the help of populist leaders and parties (McDonnell 2017). However, such populist logic rests on several key underlying assumptions: that something is wrong, someone is to blame, and it can be fixed. These assumptions do not translate well in the Chinese case. Populist reasoning in China is preemptive, almost a warning: instead of constructing an elite that is hijacking the supposedly representative and neutral institutions of government, the elite in China is the government. Populist discourses warn instead that the power of the elites can only be legitimised by them serving the interests of the people, a claim which, at first glance, the CCP supports in its official discourse. However, the authoritarian nature of Chinese politics means that it in the Party's interest to monopolise the definition of the people and its general will, as to foreclose any populist uprisings. This lands the CCP in a paradoxical position if it is to boost legitimacy from popular support bases: on the one hand, it claims to be the champion of the general will of the people, on the other hand, it is not simply reactive to the people's will but also seek to take a proactive part in shaping it. By claiming the former, the CCP could potentially risk becoming 'the other' if and when popular demands can no longer be satisfied. The latent populist tendencies in Chinese politics should therefore not be discounted, as they, like their counterparts elsewhere in the world, are expressions of deep-seated sociopolitical discontent, which if left unaddressed, could be potentially explosive in the current global climate.

\section{Conflict of Interest}

The author states that there is no conflict of interest.

\section{Appendix}

Most Popular Questions Under the 'Donald Trump' Topic on Zhihu:

1. 如何评价唐纳德. 特朗普（Donald J. Trump）当选第 45 任美国总统? [Do you think about Trump being elected as the 45th American President?] https://www.zhihu.com/question/52444153 
2. 2016 年美国大选, 希拉里输在哪儿? [Why did Hilary lose the 2016 American election?] https://www.zhihu.com/question/52463912

2. 2016 年美国总统大选对你造成了怎样的改变? [How has the 2016 American election changed you?] https://www.zhihu.com/question/51540924

3. 为什么似乎知乎上支持特朗普多, Quora 反而反对的多? [Why are there more supporters of Trump on Zhihu compared to Quora?]

https://www.zhihu.com/question/45621711

4. 为什么很多中国人鄙视西方「白左」? [Why do the Chinese despise the White Leftists?] https://www.zhihu.com/question/51331837

5. 唐纳德·特朗普有哪些值得学习的地方? [What can we learn from Donald Trump?] https://www.zhihu.com/question/45444672

6. 特朗普的当选和希拉里的落败是否能代表美国精英价值观的失败? [Is the victory of Trump and defeat of Hilary signalling the failure of American elitism?]

https://www.zhihu.com/question/52509760

\section{Bibliography}

Abts, Koen, and Stefan Rummens. 2007. "Populism Versus Democracy." Political Studies 55 (2). SAGE Publications Sage UK: London, England: 405-24.

Abts, Koen, and Stijn van Kessel. 2015. Populism. International Encyclopedia of Social \& Behavioral Sciences. Second Edition. Elsevier.

Art, David. 2011. Inside the Radical Right. Cambridge University Press.

Aslanidis, Paris. 2017. "Avoiding Bias in the Study of Populism [Chinese Political Science Review].” Chinese Political Science Review 2 (3). Springer Singapore: 266-87. doi:10.1007/s41111-017-0064-0.

Atkinson, Anthony B, and Andrea Brandolini. 2013. "On the Identification of the Middle Class." Income Inequality: Economic Disparities and the Middle Class in Affluent Countries. Stanford University Press Stanford, CA, 77-100.

Betz, Hans Georg, and Carol Johnson. 2004. "Against the Current-Stemming the Tide: the Nostalgic Ideology of the Contemporary Radical Populist Right." Journal of Political Ideologies 9 (3): 311-27.

Bi, Hongying. 2015. "The Principal Features of Online Public Opinion.” Social Sciences in Guangxi, September, 1-4. 
Bornschier, S, and H Kriesi. 2012. "The Populist Right, the Working Class, and the Changing Face of Class Politics." Class Politics and the Radical Right.

Bourke, Richard, and Quentin Skinner. 2016. Popular Sovereignty in Historical Perspective. Cambridge University Press.

Brubaker, Rogers. 2017. "Why Populism?." Theory and Society 46 (5). Springer: 357-85.

Canovan, Margaret. 2004. "Populism for Political Theorists?.” Journal of Political Ideologies 9 (3). Taylor \& Francis: 241-52.

Carrico, Kevin. 2016. Chinese Nationalism. Oxford University Press.

Chen, Jie. 2013. A Middle Class Without Democracy: Economic Growth and the Prospects for Democratization in China. Oxford University Press.

Chen, Xi. 2018. "Relative Deprivation in China." In The Oxford Companion to the Economics of China, 406-10. Oxford University Press.

Cheung, K C K. 2012. "Away From Socialism, Towards Chinese Characteristics: Confucianism and the Futures of Chinese Nationalism." China Information 26 (2). SAGE Publications: 205-18. doi:10.1177/0920203x12440548.

CNNIC, I. 2017. The 40th Statistical Report on Internet Development in China. China Internet Network Information Center (CNNIC).

Di Tella, Torcuato S. 1965. Populism and Reform in Latin America.

Durrheim, Kevin, and John Dixon. 2000. "Theories of Culture in Racist Discourse." Race and Society 3 (2). Elsevier: 93-109.

Espejo, Paulina Ochoa. 2017. "Populism and the Idea of the People." In Populism and the Idea of the People, edited by Cristóbal Rovira Kaltwasser, Paul Taggart, Paulina Ochoa Espejo, and Pierre Ostiguy, 1:1-24. Oxford University Press.

Feldman, Stanley. 2003. "Enforcing Social Conformity: a Theory of Authoritarianism." Political Psychology 24 (1). Wiley Online Library: 41-74.

Fewsmith, Joseph. 2013. "Xi Jinping's Fast Start." China Leadership Monitor 41: 1-7.

Germani, Gino. 1978. Authoritarianism, Fascism, and National Populism. Transaction Publishers.

Gidron, Noam, and Bart Bonikowski. 2013. "Varieties of Populism: Literature Review and Research Agenda." SSRN Electronic Journal. doi:10.2139/ssrn.2459387.

Hawkins, Kirk A. 2009. "Is Chávez Populist?.” Comparative Political Studies 42 (8): 104067.

Howarth, David. 2000. Discourse. Oxford University Press.

Ionescu, Ghita, and Ernest Gellner. 1969. Populism: Its Meaning and National Characteristics. Macmillan.

Jansen, R S. 2011. "Populist Mobilization: a New Theoretical Approach to Populism.” Sociological Theory.

Kaltwasser, Cristóbal Rovira, Paul Taggart, Paulina Ochoa Espejo, and Pierre Ostiguy. 2017. "Populism: an Overview of the Concept and the State of the Art." In The Oxford Handbook of Populism, edited by Cristóbal Rovira Kaltwasser, Paul Taggart, Paulina Ochoa Espejo, and Pierre Ostiguy, 1:1-27. Populism. Oxford University Press.

Kazin, Michael. 1998. The Populist Persuasion: an American History. Cornell University Press.

Krämer, Benjamin. 2014. "Media Populism: a Conceptual Clarification and Some Theses on Its Effects." Communication Theory 24 (1). Wiley Subscription Services, Inc.: 42-60. doi:10.1111/comt.12029. 
la Torre, de, Carlos. 2017. "Populism in Latin America." In The Oxford Handbook of Populism, edited by Cristóbal Rovira Kaltwasser, Paul Taggart, Paulina Ochoa Espejo, and Pierre Ostiguy, 1:1-22. Populism in Latin America. Oxford University Press.

Laclau, E. 2005a. "Populism: What's in a Name?." Populism and the Mirror of Democracy.

Laclau, Ernesto. 1977. Politics and Ideology in Marxist Theory: Capitalism, Fascism, Populism. Nlb London.

Laclau, Ernesto. 2005b. On Populist Reason. Verso.

Lee, Teng-hui. 1995. "Chinese Culture and Political Renewal." Journal of Democracy 6 (4). Johns Hopkins University Press: 3-8.

Ling, Lily HM, and Chih-yu Shih. 1998. "Confucianism with a Liberal Face: the Meaning of Democratic Politics in Postcolonial Taiwan.” The Review of Politics 60 (01). Cambridge Univ Press: 55-82.

Manion, Melanie. 2004. Corruption by Design: Building Clean Government in Mainland China and Hong Kong. Harvard University Press.

McDonnell, Daniele Albertazzi and Duncan. 2017. "Twenty-First Century Populism: the Spectre of Western European Democracy," August, 1-264.

Miao, Y. 2016a. Being Middle Class in China: Identity, Attitudes and Behaviour. Taylor \& Francis.

Miao, Ying. 2016b. "The Paradox of Middle-Class Attitudes in China: Democracy, Social Stability, and Reform." Journal of Current Chinese Affairs 45 (1): 169-90.

Miao, Ying. 2017. "Middle Class Identity in China: Subjectivity and Stratification." Asian Studies Review 41 (4). Taylor \& Francis: 629-46.

Moffitt, Benjamin, and Simon Tormey. 2014. "Rethinking Populism: Politics, Mediatisation and Political Style.” Political Studies 62 (2): 381-97.

Mudde, Cas. 2004. "The Populist Zeitgeist." Government and Opposition 39 (4). Wiley Online Library: 541-63.

Mudde, Cas. 2017. "Populism: an Ideational Approach." In The Oxford Handbook of Populism, edited by Cristóbal Rovira Kaltwasser, Paul Taggart, Paulina Ochoa Espejo, and Pierre Ostiguy, 1:1-26. Populism. Oxford University Press.

Mudde, Cas, and Cristobal Rovira Kaltwasser. 2018. "Studying Populism in Comparative Perspective: Reflections on the Contemporary and Future Research Agenda." Comparative Political Studies 51 (13). SAGE Publications Sage CA: Los Angeles, CA: 1667-93.

Mudde, Cas, and Cristóbal Rovira Kaltwasser. 2017. Populism: a Very Short Introduction. Oxford University Press.

Ostiguy, Pierre. 2017. "Populism: a Socio-Cultural Approach." In The Oxford Handbook of Populism, edited by Cristóbal Rovira Kaltwasser, Paul Taggart, Paulina Ochoa Espejo, and Pierre Ostiguy, 1:1-27. Populism. Oxford University Press.

O’brien, Kevin J, and Lianjiang Li. 2005. "Popular Contention and Its Impact in Rural China." Comparative Political Studies 38 (3). Sage Publications Sage CA: Thousand Oaks, CA: 235-59.

Panizza, Francisco. 2005. Populism and the Mirror of Democracy. Verso.

Pelinka, Anton. 2013. "Right-Wing Populism: Concept and Typology." Right-Wing Populism in Europe: Politics and Discourse. Bloomsbury London, 3-22.

Peng, Jiajin. 2017. "Big Data Report on Zhihu Core Users." Zhihu. http://www.afenxi.com/post/40943.

Peng, Lan. 2008. "A Study of the Typical Features of Chinese Netizens at Present.” Journal of Peoples University China. 
Perry, Elizabeth J. 2015. "The Populist Dream of Chinese Democracy.” Harvard-Yenching Institute Working Paper Series 74 (04). Cambridge University Press: 903-15.

Rhodes, James. 2010. "White Backlash, 'Unfairness' and Justifications of British National Party (BNP) Support.” Ethnicities 10 (1). Sage Publications Sage UK: London, England: 77-99.

Roberts, Kenneth M. 2015a. "Populism and Political Representation." In The Oxford Handbook of Politics of Development, 1:1-24. Populism and Political Representation. Oxford University Press.

Roberts, Kenneth M. 2015b. "Populism, Political Mobilizations, and Crises of Political Representation." The Promise and Perils of Populism: Global Perspectives. The University Press of Kentucky Lexington, Kentucky, 140-58.

Robinson, Neil, and Sarah Milne. 2017. "Populism and Political Development in Hybrid Regimes: Russia and the Development of Official Populism." International Political Science Review 38 (4). SAGE Publications Sage UK: London, England: 412-25.

Rocca, Jean-Louis. 2016. The Making of the Chinese Middle Class: Small Comfort and Great Expectations. Springer.

Sawer, Marian, and David Laycock. 2009. "Down with Elites and Up with Inequality: Market Populism in Australia and Canada." Commonwealth \& Comparative Politics 47 (2): 13350.

Shen, F, N Wang, Z Guo, and L Guo. 2009. "Online Network Size, Efficacy, and Opinion Expression: Assessing the Impacts of Internet Use in China." International Journal of Public Opinion Research 21 (4): 451-76. doi:10.1093/ijpor/edp046.

Taggart, Paul. 2017. "Populism in Western Europe." In The Oxford Handbook of Populism, edited by Cristóbal Rovira Kaltwasser, Paul Taggart, Paulina Ochoa Espejo, and Pierre Ostiguy, 1:1-20. Populism in Western Europe. Oxford University Press.

Taguieff, Pierre-André. 1995. "Political Science Confronts Populism: From a Conceptual Mirage to a Real Problem.” Telos 1995 (103). Telos Press: 9-43.

Tang, Wenfang. 2016. "Chinese Political Culture and Regime Sustainability.” In Populist Authoritarianism, 1-19. Oxford University Press..

Tomba, Luigi. 2004. "Creating an Urban Middle Class: Social Engineering in Beijing." The China Journal. JSTOR, 1-26.

Townsend, James R. 1977. "Chinese Populism and the Legacy of Mao Tse-Tung." Asian Survey 17 (11): 1003-15. doi:10.2307/2643349.

Weyland, Kurt. 2017. "Populism: a Political-Strategic Approach.” In The Oxford Handbook of Populism, edited by Cristóbal Rovira Kaltwasser, Paul Taggart, Paulina Ochoa Espejo, and Pierre Ostiguy, 1:1-31. Populism. Oxford University Press.

Weyland, Kurt. 2018. "Populism and Authoritarianism." Routledge Handbook of Global Populism. Routledge, 333-47.

Wodak, Ruth. 2015. The Politics of Fear: What Right-Wing Populist Discourses Mean. Sage.

Yiyu. 2017. "Big Data Report: Report on Millions of Zhihu Users.” Zhihu. July 23. http://www.jianshu.com/p/6815e9553aba.

Yong, Xu. 2017. "The Chinese Road in the Light of Historical Continuity." Social Sciences in China 38 (2). Routledge: 5-20. doi:10.1080/02529203.2017.1302227.

Zhang, Chenchen. 2019. "Right-Wing Populism with Chinese Characteristics? Identity, Otherness and Global Imaginaries in Debating World Politics Online." European Journal of International Relations. SAGE Publications Sage UK: London, England

Zhihu. 2017. “关于知乎 [About Zhihu].” Zhihu. http://zhihu.zhiye.com/a/about\%20us. 
Zhong, Yang. 2018. "Political Trust in Urban China." In Political Culture and Participation in Urban China, 73-89. Springer. 